From the Department of Visceral and Transplantation Surgery, Insel Hospital, Bern, Switzerland

\section{Invited Commentary to: "Spontaneous Splenic Rupture During Pringle Maneuver in Liver Resection for Hepatic Abscess"}

\section{K. Schilling, O. Kollmar, and M. W. Büchler}

Trauma is the most frequent cause for splenic rupture, which typically occurs along the peritoneal attachments of the splenic convexity or at the splenic hilum after deceleration trauma or as avulsion fractures of the spleen after direct lateral impact to the left lower ribcage. Spontaneous splenic ruptures are described as complications after infectious or neoplastic afflictions of the splenic parenchyma (5).

Intraoperative splenic injury usually occurs at the splenic insertion of the splenocolic ligament, especially if the left colonic flexure is not detached from the spleen.

The case reported by Kling et al. is indeed a rare case of spontaneous splenic rupture that has been reported in a similar setting only once (1). The site of rupture does not present like an intraoperative splenic injury, but was attributed by the authors to an increased intrasplenic pressure after Pringle's maneuver for a left lateral liver resection.

Control of the hepatic inflow by Pringle's maneuver is one of the measures to decrease bloodloss during major liver resection (2). While the consequences of Pringle's maneuver on systemic and pulmonary macro hemodynamic parameters have been studied in humans (3), little is known about the impact of Pringle's maneuver on the splanchnic, especially splenic circulation. Del$v a$ et al. demonstrate that Pringle's maneuver causes a significant increase in systemic peripheral vascular resistance and consequently an increase in blood pressure and a decreased cardiac index (3).

The authors here hypothesize that splenic venous congestion during Pringle's maneuver was the cause for the rupture. In the only comparable case published by Baradaran et al. (1) that ve-

Corresponding address: M. K. Schilling, M.D., Department of Visceral and Transplantation Surgery, Insel Hospital, CH-3010 Bern, Switzerland.

$++41 / 31 / 632-9723$

E-mail: martin.schilling@insel.ch nous congestion was seen histologically but was apparently absent in the case presented by Kling. Obviously a spontaneous rupture of an otherwise normal spleen would need to be preceded by an increased intracapsular pressure, which is a function not only of the venous pressure but also of the arterial inflow. As mentioned before nothing is known about splenic arterial blood flow during Pringle's maneuver so that any reasoning in that direction remains speculative.

Portal venous congestion after Pringle's maneuver would amongst other factors depend on the potency of anatomical portosystemic shunts i.e. the short gastric veins, the left gastric vein (V. coronaria ventriculi) as well as the inferior mesenteric vein. It would therefore be interesting if all of the above shunts were patent in the case presented here and if portal clamping was performed centrally or distally from the portal inflow of the left gastric vein.

What are the lessons to be learned from this case for the hepatobiliary surgeon? Pringle's maneuver does remain a valuable surgical adjunct to reduce bloodloss during hepatic resection. It is associated with only minor morbidity especially when performed in a sequential way (4). For a left lateral segmentectomy, extrahepatic control of the left pedicel or of the segment II/III branches of the left hepatic artery and left portal vein together with the left hepatic vein is usually sufficient to control excessive hepatic blood loss during resection. It might be advisable to watch the spleen after Pringle's maneuver for congestion to avoid rupture.

Finally when the spleen does rupture as in the case presented by Kling as well as the case presented by Baradaran, the spleen can often be preserved by splenorrhapy especially with the abdomen being open (6). Long term sequelae of splenectomy might thus be avoided.

\section{References}

(1) Baradaran S, Mischinger HJ, Bacher H, Werkgartner G, Karpf E, Linck FG: Spontaneous rupture of the spleen during portal triad clamping. Langenbecks Arch Chir 1995;380:266-268.

(2) Cunningham JD, Fong Y, Shriver C, Melendez J, Marx WL, Blumgart LH: One hundred consecutive resections. Blood loss, transfusion, and operative technique. Arch Surg 1994;129:1050-1056.

(3) Delva E, Camus Y, Paugam C, Parc R, Huguet C, Lienhart A: Hemodynamic effects of portal triad clamping in humans. Anesth Analg 1987;66:864-868.

(4) Man K, Fan ST, Ng IO, Lo CM, Liu CL, Wong J: Prospective evaluation of Pringle maneuver in hepatectomy for liver tumors by a randomized study. Ann Surg 1997;226:704-713.

(5) Massad M, Murr M. Razzouk B. Nassourah Z, Sankari M, Najjar F: Spontaneous splenic rupture in an adult with mumps: A case report. Surgery 1988;103:381-382.

(6) Schweizer W, Bohlen L, Gilg M, Blumgart LH: Prospective study of the early postoperative course of splenic rupture: spleen preservation versus splenectomy. Helv Chir Acta 1992;58:647-653.

\footnotetext{
MMPRESSUM: Verleger: Blackwell Wissenschafts-Verlag GesmbH. - Herausgeber: Blackwell Wissenschafts-Verlag GesmbH., gemeinsam mit der Österrejchischen Gesellschaft für Chirurgie und deren assoziierten Fachgesellschaften. - Eigentümer: Blackwell Science Ltd., Osney Mead, Oxford, GB. - Senior Editors: F. Piza, M. D. Wien, F. Helmer, M. D., Wien. - Editor-in-Chief: B. Niederle, M. D. Wien. - Co-Editors: P. Steindorfer M. D., Graz, L. Ch. Müller, M. D., Innsbruck. - Alle: Zehetnergasse 6, A-1140 Wien. - Druck: Druckerei Kahls', Dombacher Straße 101, A-1170 Wien. - Alleinige Anzeigenannahme durch den Verlag: Markus Schulz. Alle: Zehetnergasse 6, A-1140 Wien, Tel. +43/1/89406 90, Fax: +43/1/894 0690 24, E-mail: verlag@ blackwis.at, Intemet-home page: hitp://wmw.blackwis.com/aca.htm; Kur-

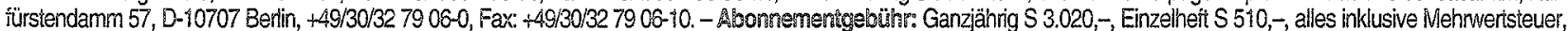
plus Versandspesen und Manipulation. Für Mitglieder der mitherausgebenden Gesellschaften und für Studierende der Medizin (bei Bezug direkt vom Verlag) emäßigt sich der Bezugspreis auf jährlich S 1.510,- (zuzüglich Versandspesen und Manipulation).

Die Bezugsdauer verlängert sich um jeweils ein Jahr, wenn nicht spätestens 6 Wochen vor Ablauf des Kalenderjahres gekündigt wird. Diese Zeitschrift ist urheberrechtlich geschützt. Die dadurch begründeten Rechte, insbesondere die der Übersetzung, des Nachdrucks, des Vortrags, der Entnahme von Abbildungen und Tabellen, der Funksendung, der Mikroverfilmung oder Vervielfältigung auf anderen Wegen und der Speicherung in Datenverarbeitungsanlagen, bleiben, auch bei nur auszugsweiser Verwertung, vorbehalten. Eine Vervielfältigung der Zeitschrift oder von Teilen daraus ist auch im Einzelfall nur in den Grenzen der Bestimmungen der einschlägigen gesetzlichen Regelungen zulässig. Sie ist grundsätzlich vergütungspllichtig. Zuwiderhandlungen unterliegen den Strafbestimmungen der Gesetze.

Die Wiedergabe von Gebrauchsnamen, Handelsnamen, Warenbezeichungen usw. in dieser Zeitschrift berechtigt auch ohne besondere Kennzeichnung nicht zur Annahme, daß solche Namen im Sinne der Warenzeichen- und Markenschutz-Gesetzgebung als frei zu betrachten wären und daher von jedermann benutzt werden dürfen.

Produkthaftung: Für Angaben über Dosierungsanweisungen und Applikationsformen kann vom Verlag keine Gewähr übernommen werden. Derartige Angaben müssen vom jeweiligen Anwender im Einzelfall an Hand anderer Literaturstellen auf ihre Richtigkeit überprüft werden.
} 